\title{
Univariate and multivariate controlled release nitrogen pairing on lettuce culture performance
}

\author{
Luiz Leonardo Ferreira ${ }^{1}$, Alex Ribeiro Bastos ${ }^{1}$, Ivan Ricardo Carvalho ${ }^{2 *}$, Marilaine de Sá Fernandes ${ }^{1}$, \\ Núbia Sousa Carrijo dos Santos ${ }^{1}$, Ariana Bertola Carnevale ${ }^{1}$ and Priscila Ferreira Batista ${ }^{1}$
} 'Centro Universitário de Mineiros, Unidade de Biociências, GO, Brasil.
2Universidade Regional do Noroeste do Estado do Rio Grande do Sul, RS, Brasil.

*Author for correspondence: carvalho.irc@gmail.com

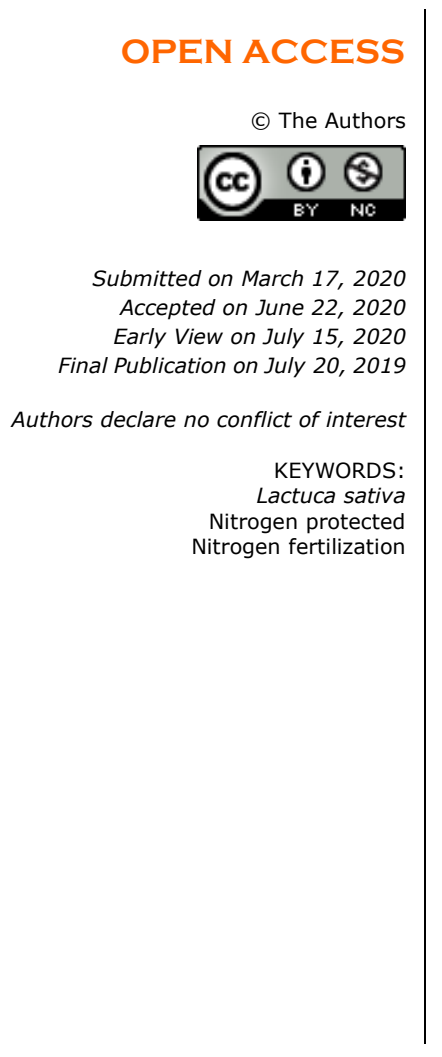

\section{ABSTRACT}

There are few studies in the literature that demonstrate the behavior of controlled release nitrogen fertilization in lettuce crop. Thus, the objective of this work was to evaluate, through univariate and multivariate pairing, the behavior of controlled release nitrogen sources on the performance of lettuce culture. The studies were conducted at the Horta dos Coqueiros property in Mineiros-GO, Brazil. The soil analyzes were taken before the experiment implementation, in the 0 to $20 \mathrm{~cm}$ layer, the soil was classified as NEOSSOL Quartzarenic. The experimental design was a randomized complete block design, with a $2 \times 2 \times 5$ factorial design corresponding to 2 lettuce genotypes (Americana cv. Lucy Brow and Crespa cv. Vanda), submitted to two controlled release $\mathrm{N}$ sources (NitroMais and Polyblen). doses (0, $75,150,225,300 \mathrm{~kg} \mathrm{ha}^{-1}$ of $\mathrm{N}$ ) performing 4 repetitions. Transplantation occurred 20 days after sowing in trays, with plant spacing of $30 \times 30$. Data collection occurred 45 days after transplantation used 5 central plants of each plot. The analyzes were performed in the Rbio $R$ interface, besides the Genes Software. The analysis of variance revealed triple interaction among the variables. Quadratic effect was expressed for both genotypes on protected nitrogen sources. For high performance of lettuce cultura in the Americana genotype cv. Lucy Brown recommends the application of protected nitrogen Polyblen at a concentration of 217.50 and NitroMais at $174.38 \mathrm{~kg} \mathrm{ha}^{-1}$ of $\mathrm{N}$, as well as the source Polyblen at a dose of $146.50 \mathrm{~kg} \mathrm{ha}^{-1}$ of $\mathrm{N}$ in the genotype Crespa cv. Vanda.

\section{Highlighted Conclusions}

1. High performance of lettuce crop in the genotype Americana cv. Lucy Brown recommends the application of controlled release nitrogen Polyblen at a concentration of 217.50 and NitroMais at $174.38 \mathrm{~kg} \mathrm{ha}^{-1}$ of $\mathrm{N}$.

2. In the Crespa cv. Vanda, the Polyblen source is at a dose of $146.50 \mathrm{~kg} \mathrm{ha}^{-1}$ of $\mathrm{N}$.

\section{INTRODUCTION}

The lettuce crop (Lactuca sativa) herbaceous plant of the Asteraceae family is one of the most cultivated and consumed leafy vegetables in the world. In Brazil, its production occurs throughout the year, much consumed in fresh form. Nascimento et al. (2017) reported that to supply the demand of the consumer market in quantity, quality and regularity of vegetables, it is necessary to use cultivation systems with high productivity. The application of fertilizers with adequate doses of nitrogen in this crop is a convenient strategy, since its basically leaf composition provides high response to the availability of this mineral (Melo at al. 2018).

The use of coated fertilizers aims to protect the nutrients from natural losses that occur when using conventional fertilization, the encapsulated nutrient in some studies has shown great importance in the economy, because the use of these fertilizers is expected to reduce the dosage used, since the nutrient is gradually released providing absorption efficiency (Silva et al. 2019).

Nitrogen $(\mathrm{N})$ is one of the nutrients that most contribute to the physiological metabolism of plants and is directly related to protein formation (Nascimento et al. 2017). The application of fertilizers with adequate doses of $\mathrm{N}$ in lettuce crop is a convenient strategy, since its basically leaf composition provides high response to the availability of this mineral (Melo et al. 2018). The efficiency of $\mathrm{N}$ can be increased by using controlled release $\mathrm{N}$-based fertilizers, which aim to keep the element in less loss-prone forms (Pedrinho et al. 2015). 
Nitrogen fertilization is one of the fundamental management techniques to enable high productivity in agriculture, however, the efficiency of nitrogen fertilizers is around $50 \%$ because there are several losses such as denitrification, leaching and volatilization. In order to increase the efficiency of nitrogen fertilizers and mitigate these losses, many companies bring several options of protected fertilizers (Almeida 2016), requiring applied research in order to generate information for producers in the sugarcane chain, to choose the best option. The fertilizer industry has been looking for other ways to reduce $\mathrm{NH}^{3}$ losses through the use of urease inhibiting substances, the main strategies used include the use of urease and nitrification inhibitors, the addition of acidifying compounds and use of polymer or gel coated urea.

In applied research the use of statistical methods facilitates data analysis, such methods can be grouped into univariate and multivariate models. These contribute to establish effective strategies to identify superior genotypes, used in traditional programs of genetic improvement (Costa et al. 2015), as well as establishment of production standards, from the analysis of joint of variation and correlations sources from the studied characters. Several studies have been developed using multivariate analysis, but few studies focused on lettuce crop production components have been developed so far.

The technology of controlled release fertilizers has brought good results in the field, since the nutrients are gradually released to the plant, avoiding the leaching of the same and thus the plant can express a greater productive efficiency. The application of compounds for urea grain coatings is a viable alternative to minimize the possible losses of the product, thus increasing its application efficiency. However, Almeida (2016), in his research with controlled release nitrogen fertilizers, observed large variations in the effectiveness of these products due to climatic conditions, soil type and quality of these fertilizers.

Controlled effect fertilization works are scarce, however, it is already known that protected nitrogen fertilization can contribute to the reduction of greenhouse gases emission and may become a trend due to the growing concern with the environment; it also decreases leaching or volatilization losses, so it is available to the plant longer. However, some studies showed no increase in production or economic viability in the use of protected fertilization when compared to the main nitrogen source of agriculture, conventional urea.

Due to the scarce studies carried out with controlled release nitrogen fertilizers in the lettuce crop, the objective of this work was to evaluate by univariate and multivariate pairing the behavior of controlled release nitrogen sources on the performance of lettuce.

\section{MATERIAL AND METHODS}

The study was conducted at the Horta dos Coqueiros estate in the municipality of Mineiros-GO, located between the geographic coordinates of $17^{\circ} 34^{\prime} 10^{\prime \prime}$ south latitude and $52^{\circ} 33^{\prime} 04^{\prime \prime}$ west longitude, with an average altitude of $760 \mathrm{~m}$. The experimental area is classified as Aw (hot dry) climate (Köppen and Geiger 1936). The soil of the experimental area was classified NEOSSOLO Quartzarenico (Santos et al., 2018). Chemical and particle size analyzes of the $0-20 \mathrm{~cm}$ layer were performed before the experiment installation, revealing the following results: $\mathrm{pH}$ in $\mathrm{CaCl}_{2} 0.01 \mathrm{~mol} \mathrm{~L}^{-1}$ 6.1; phosphorus in Mehlich1 $172 \mathrm{mg} \mathrm{dm}^{-3}$; potassium 0.12, calcium 7.5, magnesium 0.9, aluminum 0 , hydrogen 16 , in $\mathrm{cmol}_{\mathrm{c}} \mathrm{dm}^{-3}$; clay 14 , silt 5 and sand $81 \mathrm{in} \%$. The analyzes were performed according to the methodology of Embrapa (2009).

The experimental design was randomized blocks in factorial $2 \times 2 \times 5$, corresponding to 2 lettuce genotypes (Americana cv. Lucy Brown and Crespa cv. Vanda), submitted to 2 controlled release nitrogen sources (NitroMais and Polyblen), both in 5 Nitrogen contents $\left(0,75,150,225\right.$ and $300 \mathrm{~kg}$ of $\left.\mathrm{N} \mathrm{ha}^{-1}\right)$, in 4 repetitions.

The tillage was performed in the conventional system with plowing and harrowing. Each plot was sized at 0.80 $\mathrm{m}$ in length by $1.20 \mathrm{~m}$ in width and $0.10 \mathrm{~m}$ in height. Fertilizers in their respective doses were incorporated in the 0 $5 \mathrm{~cm}$ layer on the day of seedling transplantation, which took place on June 17, 2017. Mulching was used. The seedlings were grown in polystyrene trays containing 200 cells, filled with Plantmax commercial substrate. The seedlings were transplanted 20 days after sowing in the trays. The plots consisted of 15 plants each, spaced at $0.3 \times 0.3 \mathrm{~m}$. During the execution of the experiment the control of insects and pathogens were performed whenever necessary, respecting the good practices and the integrated management. The irrigation system adopted was Santeno, being used whenever necessary, keeping the soil moisture close to the field capacity.

Data collection was performed at 45 days after seedling transplantation using 5 central plants from each plot where it was evaluated: stem height $(\mathrm{cm})$ using a millimeter ruler, stem diameter $(\mathrm{cm})$ with aid of caliper, head diameter $(\mathrm{cm})$ by millimeter ruler, number of commercial sheet (units) obtained by the sum of these and fresh head weight $(\mathrm{g})$ taken with a precision scale $0.001 \mathrm{~g}$.

The obtained data was submitted to the assumptions of the statistical model, verifying the normality and homogeneity of the residual variances, as well as the additivity of the model. Afterwards, the analysis of variance 
was performed in order to identify the interaction between the genotypes of lettuce $(G) x$ nitrogen sources $(F N) x$ nitrogen levels $(T N)$ of nitrogen sources. When verifying significant interaction these were broken down to simple effects by Tukey test at $5 \%$ probability.

Next, genotypes $x$ nitrogen sources were described as a function of nitrogen content, performing the polynomial regression by testing the linear and quadratic models, and choosing the significant models that will present the highest correlation value with the means, observing the significance of the $F$ test. Subsequently, the variables were subjected to linear correlation in order to understand the tendency of association, and their significance was based on $5 \%$ probability by the $t$ test.

The path analysis was performed from the phenotypic correlation matrix, considering the PFC as the dependent variable and the others as explanatory. Identifying the presence of high multicollinearity among the data, the path analysis was performed under multicollinearity, with subsequent adjustment of the $\mathrm{k}$ factor to the diagonal elements of the correlation matrix. After the genetic dissimilarity was proceeded by the Mahalanobis algorithm where the matrix of the residues was weighted, the phylogenetic tree was constructed through the UPGMA grouping and Tocher optimized groups. Subsequently, the biplot canonical variables method was used to visualize the general variability of the experiment and the multivariate trends. Character matrix data were subjected to unsupervised computational learning through Artificial Neural Networks using K-means and Kohonen Map algorithms. The analyzes were performed in Rbio R interface (Bhering 2017), in addition to Software Genes (Cruz 2016).

\section{RESULTS AND DISCUSSION}

Analysis of variance revealed triple interaction (GxFNxTN) in the variables ALT plant height, DCL stem diameter and DCA head diameter $(p \leq 0.01)$. Significant difference was also reported in the double interactions for ALT characteristics, NFC commercial leaf number and fresh head weight PFC (GxFN), as well as in interactions (FNxTN) and $(G \times T N)$ for ALT, DCL and DCA $(p \leq 0.01)$. The main effects were significantly described for all morphological observations at source of variation G, for NF in DCA, NFC and PFC, as well as, DCA, NFC and ALT in the increasing values of TN ( $\leq 0.01)$ (Table 1). Significant differences were also reported in lettuce crop characters in the works of Auler et al. (2015), Silva et al. (2017), Oliveira et al. (2017) and Yeshiwas et al. (2018).

\begin{tabular}{|c|c|c|c|c|c|c|}
\hline FV & $\mathrm{GL}$ & $\overline{A L T}$ & $\overline{D C L}$ & $\overline{D C A}$ & NFC & PFC \\
\hline GxFNxTN & 4 & $0.19^{* *}$ & $0.09^{* *}$ & $3.87^{\star *}$ & $2.24^{\text {ns }}$ & $4,309.05^{\text {ns }}$ \\
\hline GxFN & 1 & $0.50^{\star \star}$ & $0.00^{\text {ns }}$ & $3.32^{\text {ns }}$ & $15.24^{\star \star}$ & $64,524.80^{* *}$ \\
\hline GxTN & 4 & $0.94^{* *}$ & $0.12^{\star *}$ & $15.57^{\star \star}$ & $0.66^{\mathrm{ns}}$ & $17,868.13^{\star *}$ \\
\hline FNxTN & 4 & $0.78^{* \star}$ & $0.10^{\star *}$ & $4.37^{\star \star}$ & $1.99^{\text {ns }}$ & $5,654 \cdot 13^{\text {ns }}$ \\
\hline Genotypes (G) & 1 & $126.35^{* *}$ & $20.80^{* \star}$ & $252.90^{* *}$ & $577.75^{\star \star}$ & $36,380.450^{* *}$ \\
\hline Nitrogen sources (FN) & 1 & $0.02^{\text {ns }}$ & $0.05^{\mathrm{ns}}$ & $14.97^{\star \star}$ & $28.29^{\star \star}$ & $116,739.20^{* *}$ \\
\hline Nitrogen contents (TN) & 4 & $1.50^{* *}$ & $0.03^{\text {ns }}$ & $11.82^{* \star}$ & $8.43^{\star *}$ & $9,582.00^{\text {ns }}$ \\
\hline Blocks & 3 & 0.03 & 0.22 & 1.60 & 5.71 & $6,677.78$ \\
\hline Residue & - & 0.04 & 0.02 & 1.39 & 1.05 & $2,797.74$ \\
\hline $\mathrm{CV}$ & - & 3.82 & 5.18 & 2.98 & 4.18 & 9.38 \\
\hline
\end{tabular}

The breakdown of the genotype $x$ nitrogen content interaction represented by (Table 2) revealed that the ALT, DCL and DCA variables had higher magnitude in Crespa genotype, following this reasoning only at dose 0 for PFC. In the genotype $x$ nitrogen source interaction, the Crespa genotype had higher ALT and NFC values independent of the nitrogen source, whereas the PFC did not differ among the genotypes for the Polyblen source, being higher in Americana in the NitroMais source (Table 2). The increase in the number of leaves per plant with the increase of $\mathrm{N}$ may be due to nitrogen that may have contributed to the production of new leaf shoots and vigor in vegetative growth, which is directly responsible for the increase in leaf number (Yeshiwas et al. 2018).

For the nitrogen source $\mathrm{x}$ nitrogen content interaction, the NitroMais source always corresponded to the highest averages in the characteristics of ALT, DCL and DCA, except only at the concentration of 150 (Table 2). In the work of Awaad et al. (2016), the results indicated that the application of slow release nitrogen fertilizer, alone or combined with potassium sulfate, significantly improved the yield and yield quality of lettuce plants cultivated in sandy soil. 
Table 2. Breakdown of ALT plant height, DCL stem diameter, DCA head diameter, commercial NFC leaf number and fresh weight of PFC head of lettuce genotypes at different nitrogen contents from different nitrogen sources. UNIFIMES, Mineiros-GO, Brazil, 2020.

\begin{tabular}{|c|c|c|c|c|c|c|c|c|c|c|}
\hline \multicolumn{11}{|c|}{ Genotypes G x TN Nitrogen contents } \\
\hline \multirow{3}{*}{$\begin{array}{l}\text { Nitrogen } \\
\text { contents }\end{array}$} & \multicolumn{3}{|l|}{ ALT } & \multicolumn{2}{|l|}{ DCL } & \multicolumn{3}{|l|}{ DCA } & \multicolumn{2}{|c|}{ PFC } \\
\hline & \multicolumn{3}{|l|}{ Genotypes } & \multicolumn{2}{|l|}{ Genotypes } & \multicolumn{3}{|l|}{ Genotypes } & \multicolumn{2}{|l|}{ Genotypes } \\
\hline & Americana & \multicolumn{2}{|l|}{ Crespa } & Americana & Crespa & Americana & \multicolumn{2}{|l|}{ Crespa } & Americana & Crespa \\
\hline 0 & $4.45 \mathrm{~B}$ & $7.53 \mathrm{~A}$ & & $2.41 \mathrm{~B}$ & $3.73 \mathrm{~A}$ & $33.92 \mathrm{~B}$ & $41.87 \mathrm{~A}$ & & $494.37 \mathrm{~B}$ & $559.50 \mathrm{~A}$ \\
\hline 75 & $4.66 \mathrm{~B}$ & $6.77 \mathrm{~A}$ & & $2.50 \mathrm{~B}$ & $3.50 \mathrm{~A}$ & $37.96 \mathrm{~B}$ & $42.93 \mathrm{~A}$ & & $649.87 \mathrm{~A}$ & $538.12 \mathrm{~B}$ \\
\hline 150 & $4.31 \mathrm{~B}$ & $6.80 \mathrm{~A}$ & & $2.55 \mathrm{~B}$ & $3.48 \mathrm{~A}$ & $38.28 \mathrm{~B}$ & $41.30 \mathrm{~A}$ & & $595.12 \mathrm{~A}$ & $540.00 \mathrm{~B}$ \\
\hline 225 & $4.27 \mathrm{~B}$ & $6.24 \mathrm{~A}$ & & $2.56 \mathrm{~B}$ & $3.40 \mathrm{~A}$ & $39.12 \mathrm{~B}$ & $41.44 \mathrm{~A}$ & & $589.50 \mathrm{~A}$ & $555.87 \mathrm{~A}$ \\
\hline 300 & $3.83 \mathrm{~B}$ & $6.74 \mathrm{~A}$ & & $2.44 \mathrm{~B}$ & $3.45 \mathrm{~A}$ & $38.31 \mathrm{~B}$ & $41.03 \mathrm{~A}$ & & $597.12 \mathrm{~A}$ & $519.25 \mathrm{~B}$ \\
\hline \multicolumn{11}{|c|}{ Genotypes G x TN Nitrogen contents } \\
\hline \multirow{3}{*}{ Genotypes } & \multirow{2}{*}{\multicolumn{2}{|c|}{$\begin{array}{l}\text { ALT } \\
\text { Nitrogen sources }\end{array}$}} & & & NFC & & & \multicolumn{3}{|l|}{ PFC } \\
\hline & & & & & \multicolumn{2}{|l|}{ Nitrogen sources } & & \multicolumn{2}{|c|}{ Nitrogen sources } & \\
\hline & \multicolumn{2}{|c|}{$\begin{array}{l}\text { Nitrogen sources } \\
\text { Polyblen }\end{array}$} & \multicolumn{2}{|l|}{ NitroMais } & Polyblen & \multicolumn{2}{|l|}{ NitroMais } & \multicolumn{2}{|l|}{ Polyblen } & NitroMais \\
\hline Americana & \multicolumn{2}{|l|}{$4.21 \mathrm{bB}$} & $4.40 \mathrm{bA}$ & & $22.10 \mathrm{bA}$ & $21.77 \mathrm{bA}$ & & $518.60 \mathrm{aB}$ & & $651.60 \mathrm{aA}$ \\
\hline Crespa & $6.88 \mathrm{aA}$ & & $6.75 \mathrm{Aa}$ & & $28.37 \mathrm{aA}$ & $26.25 \mathrm{aB}$ & & $532.75 \mathrm{aA}$ & & $552.35 \mathrm{bA}$ \\
\hline Nitrogen so & $\operatorname{ces} \mathrm{FN} \times \mathrm{TN} \mathrm{N}$ & itrogen c & ontents & & & & & & & \\
\hline & ALT & & & & $\mathrm{DCL}$ & & & DCA & & \\
\hline $\begin{array}{l}\text { Nitrogen } \\
\text { contents }\end{array}$ & Nitrogen & sources & & & Nitrogen sources & & & Nitrogen $s$ & sources & \\
\hline & Polyblen & & NitroMais & & Polyblen & NitroMais & & Polyblen & & NitroMais \\
\hline 0 & $6.09 \mathrm{~A}$ & & $5.89 \mathrm{~A}$ & & $3.01 \mathrm{~A}$ & $3.13 \mathrm{~A}$ & & $37.33 \mathrm{~A}$ & & $38.46 \mathrm{~A}$ \\
\hline 75 & $5.40 \mathrm{~B}$ & & $6.04 \mathrm{~A}$ & & $2.85 \mathrm{~B}$ & $3.15 \mathrm{~A}$ & & $39.30 \mathrm{~B}$ & & $41.59 \mathrm{~A}$ \\
\hline 150 & $5.82 \mathrm{~A}$ & & $5.29 \mathrm{~B}$ & & $3.07 \mathrm{~A}$ & $2.96 \mathrm{~A}$ & & $39.21 \mathrm{~A}$ & & $40.37 \mathrm{~A}$ \\
\hline 225 & $5.26 \mathrm{~A}$ & & $5.26 \mathrm{~A}$ & & $2.98 \mathrm{~A}$ & $2.98 \mathrm{~A}$ & & $39.50 \mathrm{~B}$ & & $41.06 \mathrm{~A}$ \\
\hline 300 & $5.16 \mathrm{~B}$ & & $5.41 \mathrm{~A}$ & & $2.97 \mathrm{~A}$ & $2.91 \mathrm{~A}$ & & $40.18 \mathrm{~A}$ & & $39.16 \mathrm{~A}$ \\
\hline
\end{tabular}

Averages followed by the same letters lowercase vertically and uppercase horizontally do not differ statistically by Tukey's test at $5 \%$ probability.

Quadratic effect was observed in ALT, DCL, DCA, NFC and PFC in the Americana genotype for both nitrogen sources, whereas Crespa genotype showed similar behavior for DCL and DCA in NitroMais and NFC and PFC fertilizer in Polyblen (Figure 1 and Table 3). The maximum NFC values were very similar in Americana lettuce with 22.65 and 22.20 leaves plant ${ }^{-1}$ Polyblen and NitroMais, respectively, with slightly higher average on Crespa 29.09 with Polyblen, where the optimized doses were 107.62, 121.51 and $101.75 \mathrm{~kg}$. ha-1 of $\mathrm{N}$, in this order (Figure 1D). The results corroborate with Rezende et al. (2017) when reaching average of 23 leaves plant $^{-1}$ with optimized dose of $171 \mathrm{~kg} \mathrm{ha}^{-1}$ of $\mathrm{N}$ with lettuce Crespa cv. Vera But higher than that of (Araújo et al. 2011), which accounted for 14.9 leaves plant ${ }^{-1}$.

The optimized PFC in the Americana genotype ranged from $0.55 \mathrm{~g} \mathrm{plant}^{-1}$ in Polyblen to $0.71 \mathrm{~g} \mathrm{plant}^{-1}$ with NitroMais source at concentrations of 217.50 and $174.38 \mathrm{~kg} \mathrm{ha}^{-1}$ of $\mathrm{N}$, respectively. In the Polyblen source the optimized concentration was $146.50 \mathrm{~kg} \mathrm{ha}^{-1}$ of $\mathrm{N}$ which corresponded to PFC of $0.53 \mathrm{~g} \mathrm{plant}^{-1}$ (Figure 1E). High nitrogen doses can intoxicate plant metabolism, interrupting its growth rate and pre-disposing to insect and pathogen attack due to the low proteosynthesis/proteolysis ratio. For Yeshiwas et al. (2018), high rates of nitrogen application adversely affect product quality, increasing nitrate accumulation in leaves that directly influence human health.

Pedrinho et al. (2015) concluded that the use of protected (encapsulated) urea in Americana lettuce crop did not increase yield when compared to managed urea in planting, on the other hand, the use of managed urea in planting and in cover; showed higher productivity than the protected urea source. As in Ferreira et al. (2019a) when approaching in their research that the production components in corn crop were enhanced by the presence of Polyblen.

The simple correlation network expressed for the Americana genotype formed significant pairs positive for DCA $x$ PFC and negative for ALT $\times$ DCA, ALT x NFC, and ALT x PFC when fertilized with Polyblen (Figure 2A), whereas with NitroMore fertilizer. Significant pairs were positively formed between NFC x ALT, PFC x NFC, PFC x ALT, DCL $x$ DCA, and PFC $x$ DCA (Figure $2 B$ ). In the Crespa genotype the correlations were only positive with the ALT $x$ DCL pair and the DCL $\times A L T, P F C \times D C L$ and DCA $\times$ DCL pairs in the Polyblen (Figure 2C) and NitroMais (Figure 2D) nitrogen sources, respectively. The simple correlation network aims to evaluate the positive and negative 
correlation between the analyzed variables with values ranging between -1 and 1 , according to Dutra (2018), the more the absolute value of the correlation coefficient approaches 1, the stronger is the correlation between the characters. Correlations between lettuce characters were also diagnosed by Ferreira et al. (2019a).

\section{$\square$ Americana-Polyblen $\diamond$ Americana-NitroMais \\ $\triangle$ Crespa-Polyblen}
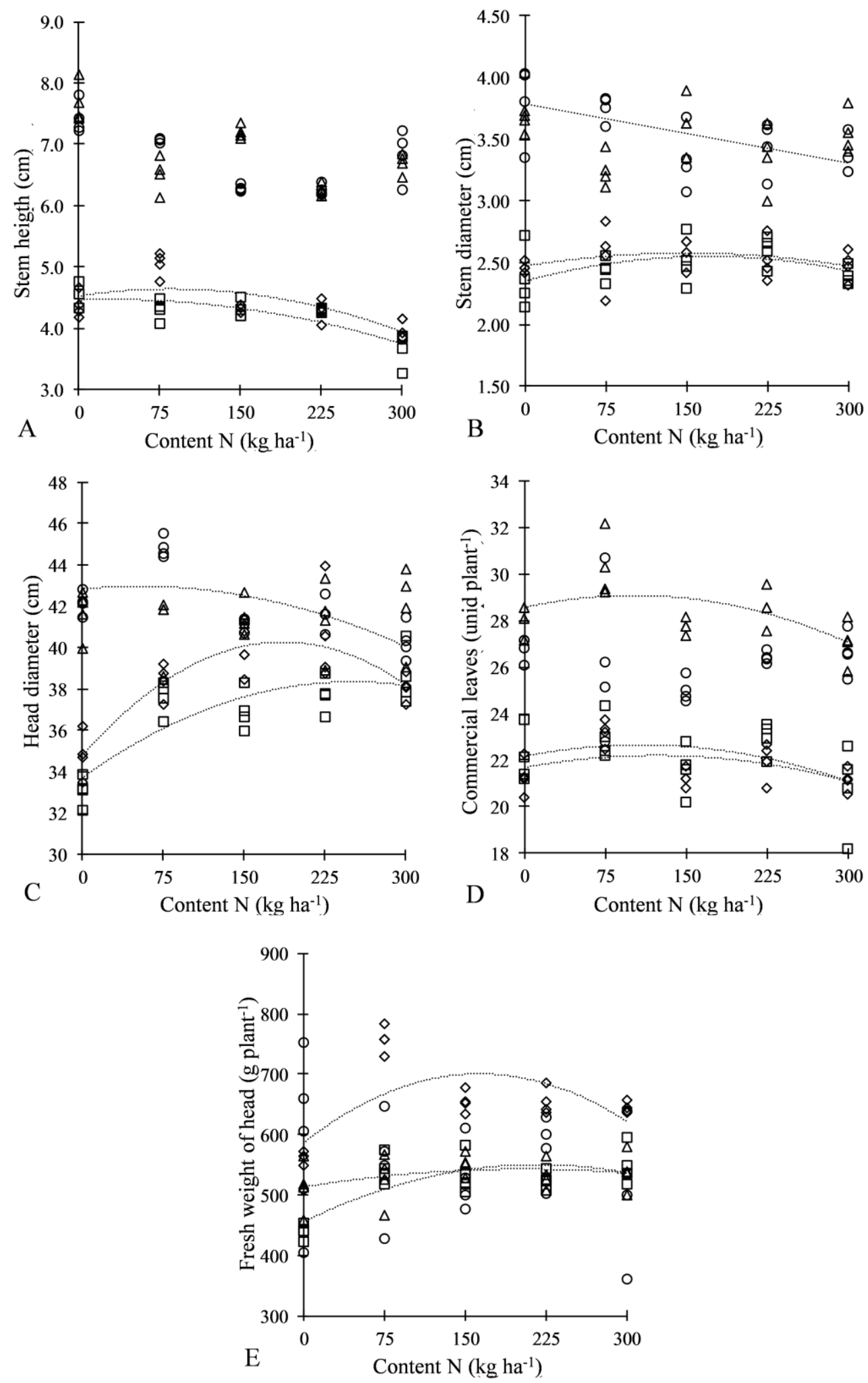

Figure 1. Stem height ALT (A), stem diameter DCL (B), head diameter DCA (C), number of commercial leaves NFC (D) and fresh weight of head PFC (E) of Americana lettuce genotypes and Crespa, as a function of $\mathbf{N}$ content in $\mathrm{kg} \mathrm{ha}^{-1}$ of NitroMais and Polyblen nitrogen sources. UNIFIMES, Mineiros-GO, Brazil, 2020. 
Table 3. Equations and R2 for the variables ALT plant height, DCL stem diameter, DCA head diameter, NFC commercial leaf number and fresh PFC head weight of lettuce genotypes and Crespa, as a function of $\mathbf{N}$ in $\mathbf{k g}$ ha $^{-1}$ from NitroMais and Polyblen nitrogen sources. UNIFIMES, Mineiros-GO, Brazil, 2020.

\begin{tabular}{|c|c|c|c|c|}
\hline Genotype & Nitrogen source & Variable & Mathematical model & $\mathrm{R}^{2}$ \\
\hline \multirow{2}{*}{ Americana } & Polyblen & \multirow{4}{*}{ ALT } & $\square \hat{\mathrm{y}}: 4.457453+0.000645^{\mathrm{ns}} \mathrm{x}-0.00001^{*} \mathrm{x}^{2}$ & 0.84 \\
\hline & NitroMais & & $\diamond \hat{y}: 4.526143+0.002616^{n s} x-0.000015^{*} x^{2}$ & 0.85 \\
\hline \multirow{2}{*}{ Crespa } & Polyblen & & $\Delta \hat{y}: \mu: 6.86^{\text {ns }}$ & \\
\hline & NitroMais & & $\circ \hat{\mathrm{y}}: \mu: 6.76^{\mathrm{ns}}$ & \\
\hline \multirow{2}{*}{ Americana } & Polyblen & \multirow{4}{*}{$\mathrm{DCL}$} & $\square$ AP ŷ: $2.350761+0.002366^{*} x-0.000007^{* *} x^{2}$ & 0.75 \\
\hline & NitroMais & & $\diamond \mathrm{AF} \hat{\mathrm{y}}: 2.47281+0.001405^{*} \mathrm{x}-0.000005^{*} \mathrm{x}^{2}$ & 0.91 \\
\hline \multirow{2}{*}{ Crespa } & Polyblen & & $\Delta \hat{\mathrm{y}}: \mu: 3.49^{\mathrm{ns}}$ & \\
\hline & NitroMais & & $\circ$ CF ŷ: 3.785334-0.001616*x & 0.74 \\
\hline \multirow{2}{*}{ Americana } & Polyblen & \multirow{4}{*}{ DCA } & $\square$ AP ŷ: $33.697143+0.037143^{* *} x-0.000074^{*} x^{2}$ & 0.81 \\
\hline & NitroMais & & $\diamond \mathrm{AF} \hat{\mathrm{y}}: 34.755358+0.059209^{* *} x-0.000159^{* *} x^{2}$ & 0.97 \\
\hline \multirow{2}{*}{ Crespa } & Polyblen & & $\Delta \hat{\mathrm{y}}: \mu: 41.48^{\mathrm{ns}}$ & \\
\hline & NitroMais & & $\circ$ CF ŷ: $42.834237+0.005181^{n s} x-0.000048^{*} x^{2}$ & 0.79 \\
\hline \multirow{2}{*}{ Americana } & Polyblen & \multirow{4}{*}{ NFC } & $\square$ AP ŷ: $22.166167+0.00904^{n s} x-0.000042^{*} x^{2}$ & 0.84 \\
\hline & NitroMais & & $\diamond \mathrm{AF} \hat{\mathrm{y}:}: 21.683953+0.008506^{\mathrm{ns}} \mathrm{x}-0.000035^{*} x^{2}$ & 0.85 \\
\hline \multirow{2}{*}{ Crespa } & Polyblen & & $\Delta \mathrm{CP} \hat{\mathrm{y}}: 28.559357+0.010378^{\mathrm{ns}} \mathrm{x}-0.000051^{*} \mathrm{x}^{2}$ & 0.84 \\
\hline & NitroMais & & $\circ$ ŷ: $\mu: 26.25^{\mathrm{ns}}$ & \\
\hline \multirow{2}{*}{ Americana } & Polyblen & \multirow{4}{*}{ PFC } & $\square$ AP ŷ: $0.455629+0.00087^{*} x-0.000002^{* *} x^{2}$ & 0.73 \\
\hline & NitroMais & & $\diamond$ AF $\hat{y}: 0.586444+0.001395^{* *} x-0.000004^{* *} x^{2}$ & 0.84 \\
\hline \multirow{2}{*}{ Crespa } & Polyblen & & $\Delta \mathrm{CP} \hat{\mathrm{y}:}: 0.513144+0.000293^{\mathrm{ns}} \mathrm{x}-0.000001^{*} \mathrm{x}^{2}$ & 0.78 \\
\hline & NitroMais & & $\circ \hat{y}: \mu: 552.40^{\text {ns }}$ & \\
\hline
\end{tabular}

$\mathbf{A}$

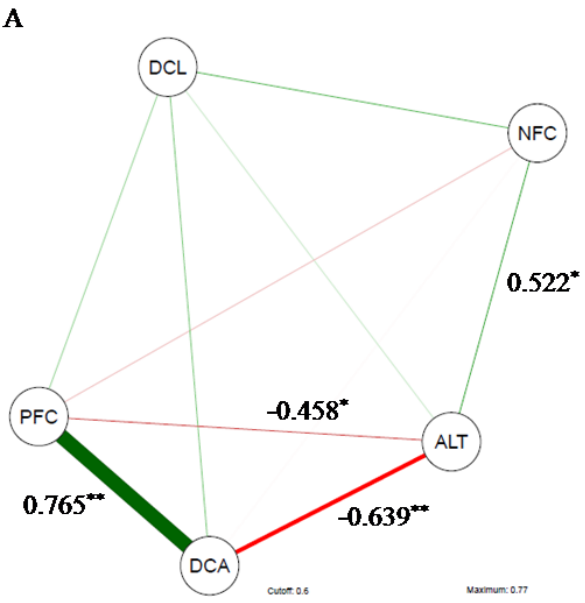

C

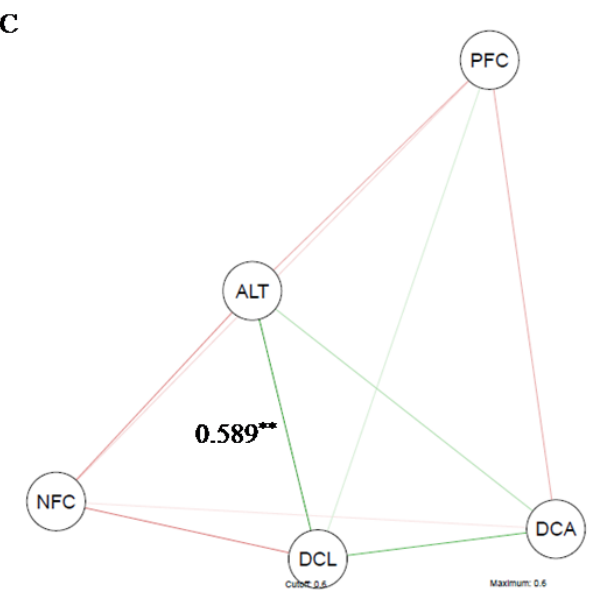

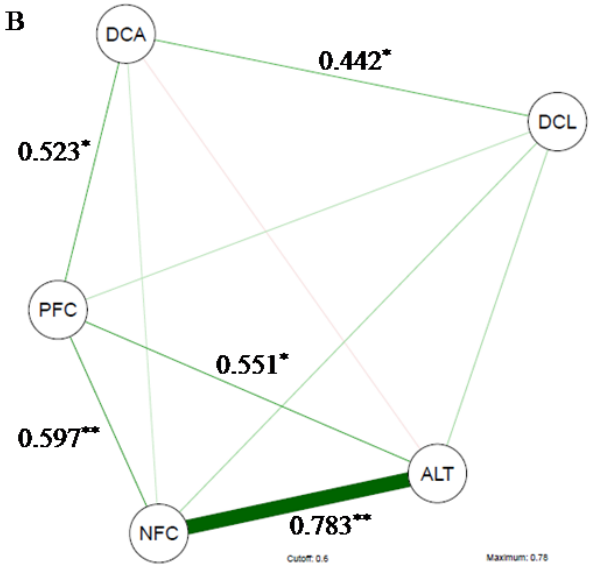

D

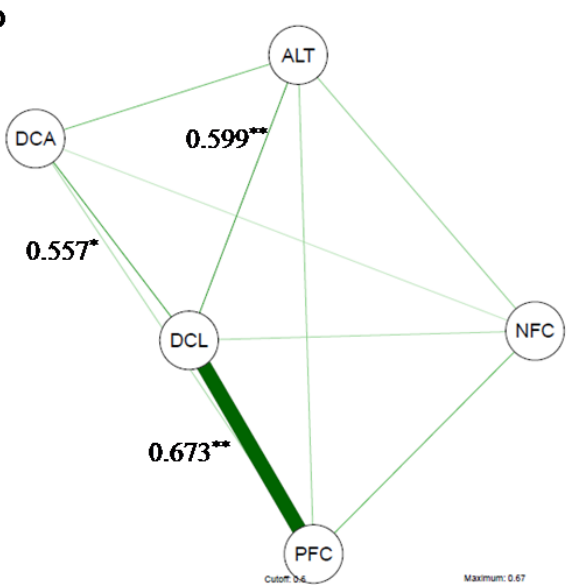

Figure 2. Simple correlation network applied on ALT plant height, DCL stem diameter, DCA head diameter, NFC commercial leaf number, and fresh PFC head weight characteristics of Americana lettuce genotypes fertilized with Polyblen nitrogen sources (A) and NitroMais (B), and Crespa lettuce fertilized with nitrogen sources Polyblen (C) and NitroMais (D). Red lines represent negative correlations and green

lines represent positive corrections. The line thickness is proportional to the magnitude of the correlation. UNIFIMES, Mineiros - GO. Brazil. 2020. Significant at $5 \%{ }^{*}$ and $1 \%{ }^{* \star}$, probability by test t. 
Estimates of direct and indirect effects in the path analysis of explanatory traits on commercial fresh weight PFC of lettuce presented the determination coefficients of the order of $0.80,0.35,0.88$ and 0.49 in NitroMais lettuce, Crespa lettuce with Polyblen, Americana Lettuce with Polyblen and Crop Lettuce with NitroMais, respectively (Figure 3). Track analysis consists of the unfolding of direct and indirect effect correlations, and the indirect influence of one variable, independent of the others, on the other is measured, where estimates are obtained by regression equations (Cruz et al. 2004).

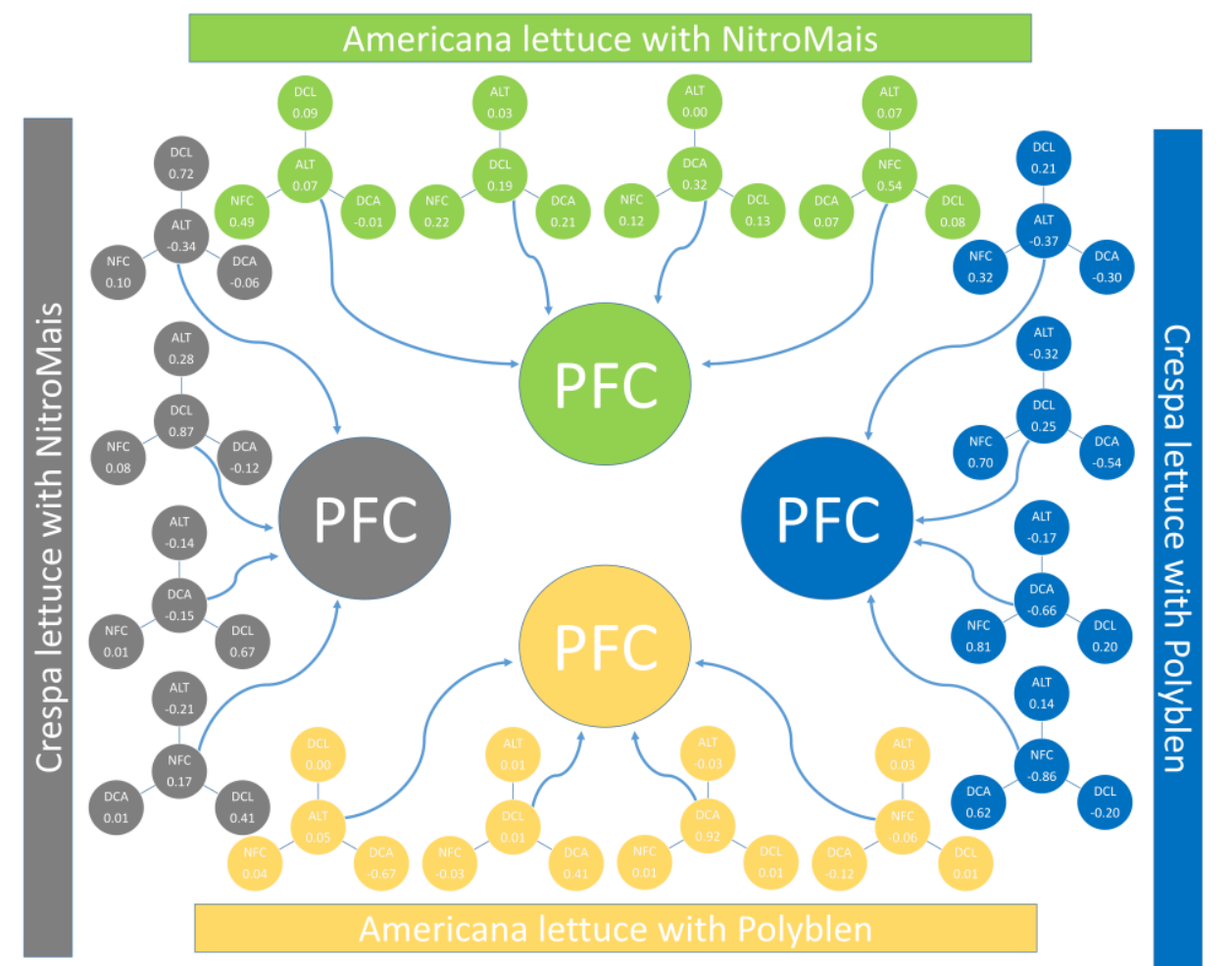

Figure 3. Causal diagram of estimates of direct and indirect effects on phenotypic path analysis of explanatory characters ALT plant height, DCL stem diameter, DCA head diameter, and NFC commercial leaf number on the fresh weight of the PFC head of the genotypes of Americana Lettuce and Crespa fertilized with the nitrogen sources Polyblen and NitroMais. UNIFIMES, Mineiros-GO, Brazil, 2020.

Biologically we can see that to obtain high PFC in NitroMais fertilized lettuce, it is necessary that plants present high averages for the characters of DCL, DCA and NFC, but with Polyblen the pattern changes, with elevation only in DCA. Crespa lettuce should have a pattern of reduction in ALT and DCA and increase in DCL and NFC in the presence of NitroMais, while in Polyblen, the low averages for ALT, DCA and NFC, as well as high values for DCL are necessary for high performance of the PFC of this genotype (Figure 3).

The phylogenetic tree was built based on the Mahalanobis algorithm, using the triple interaction described in Table 1, with the formation of 20 treatments identified by taking 5 parameters data. Thus, it was observed the formation of two major main groups defined by black and yellow coloration, which corresponded to the presence of Crespa and Americana genotypes, respectively. The Americana genotype formed 4 subgroups, AP_0 and AN_75 individually, AN_300, AN_150 and AN_225 forming the third and AP_300, AN_0, AP_75, AP_150 and AP_225 in the fourth group. In the Crespa genotype three subgroups were formed, the first consisting of CN_300, CN_150, CN_225 and CP_300, followed by CP_225 and CP_75, and the third formed by CN_75, CN_0, CP_0 and CP_150 (Figure 4).

In analyzing the overall treatment averages, the formation of the subgroups of the Americana genotype is based on the PFC, where the AP_0 and NA_75 groups performed the lowest and highest PFC averages respectively, the other subgroups of the Americana cultivar maintained the proximal averages among themselves. However, in the Crespa genotype group, the ALT variable was crucial in the formation of the third group subgroup, standing out for the higher means of ALT.

The first canonical pair explained $89.4 \%$ and the second $6 \%$ of the data variation, accounting for a total explanation of $95.4 \%$, as in Auler et al. (2015) who found a full explanation of the data of $84.70 \%$ in lettuce crop. Oliveira et al. (2017) and Silva et al. (2018) also reported the importance of canonical variables in lettuce crop. 


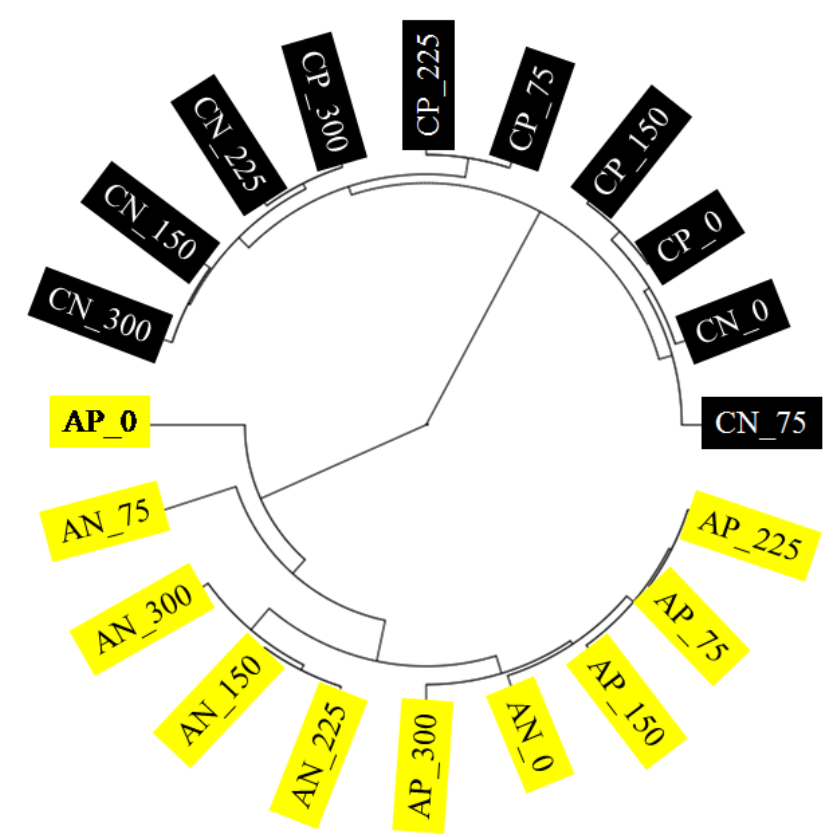

Figure 4. Phylogenetic tree constructed based on the Mahalanobis algorithm, with UPGMA clustering and Tocher optimized groups through the combinations of lettuce genotypes (Americana - A and Crespa - C), nitrogen sources (Polyblen - $\mathrm{P}$ and NitroMais $-\mathrm{N}$ ) in different nitrogen contents $(0,75$, 150,225 and $300 \mathrm{~kg}$ of $\mathrm{N} \mathrm{ha}^{-1}$ ). Variables used: ALT plant height, DCL stem diameter, DCA head diameter, NFC commercial leaf number and fresh PFC head weight. UNIFIMES, Mineiros-GO, Brazil, 2020.

The ALT, DCL and DCA variables were similar to each other. The variable PFC presented behavior very different from the other characteristics analyzed. The most evident affinity was the treatment of Crespa genotype in Polyblen nitrogen fertilizer (CP_0) in NFC character, whereas the other treatments, especially those with the presence of lettuce, did not show any affinity relationship with characteristics taken in the present work (Figure 5).

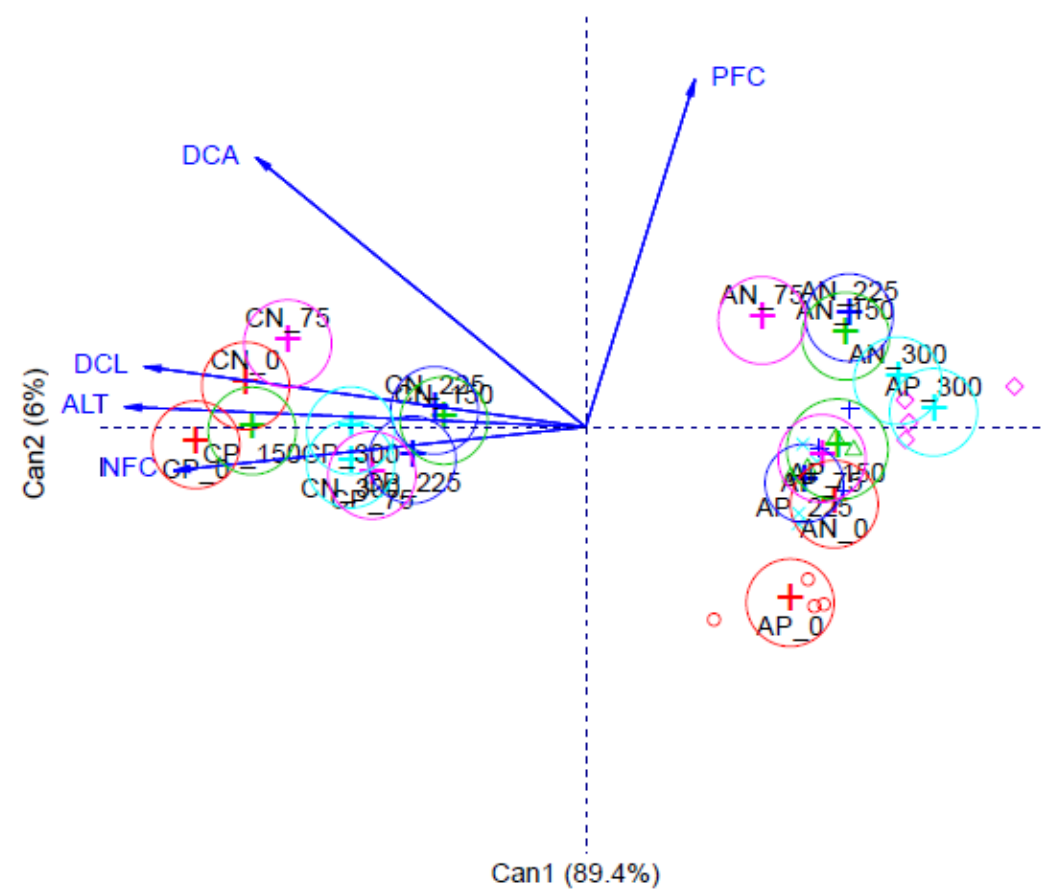

Figure 5. Canonical variable analysis obtained through the Mahalanobis algorithm of the characters ALT plant height, DCL stem diameter, DCA head diameter, NFC commercial leaf number, and fresh PFC head weight for lettuce genotype combinations (Americana - A and Crespa - C), nitrogen sources (Polyblen - $\mathrm{P}$ and NitroMais - $\mathrm{N}$ ) in different nitrogen contents $(0,75,150,225$ and $300 \mathrm{~kg}$ of $\mathrm{N} \mathrm{ha}^{-1}$ ). UNIFIMES, Mineiros-GO, Brazil, 2020. 
RNA Artificial Neural Networks are composed of a fundamental information processing unit known as a neuron, and the organization and structure of the connections between these neurons define the architecture of the network. In a general way, architectures present an input layer, zero or more intermediate or hidden layers and an output layer. In lettuce culture with morphoagronomic characters, there are few or nonexistent studies in the literature using the RNA technique.

The neural network was obtained by Kohonen Map assembled through the learning rate of 0.5 , with 2 rows and 2 columns, forming 4 centromeres, with the participation of 20 neurons coming from the triple interaction (2 lettuce genotypes $\times 2$ nitrogen sources $\times 5$ nitrogen source levels), taking the characteristics of plant height ALT, stem diameter DCL, head diameter DCA, commercial leaf number NFC and fresh weight head PFC. Centromeres I and III were close, as well as in II and IV due to the high contrasting expressiveness among genotypes (Figure 6).

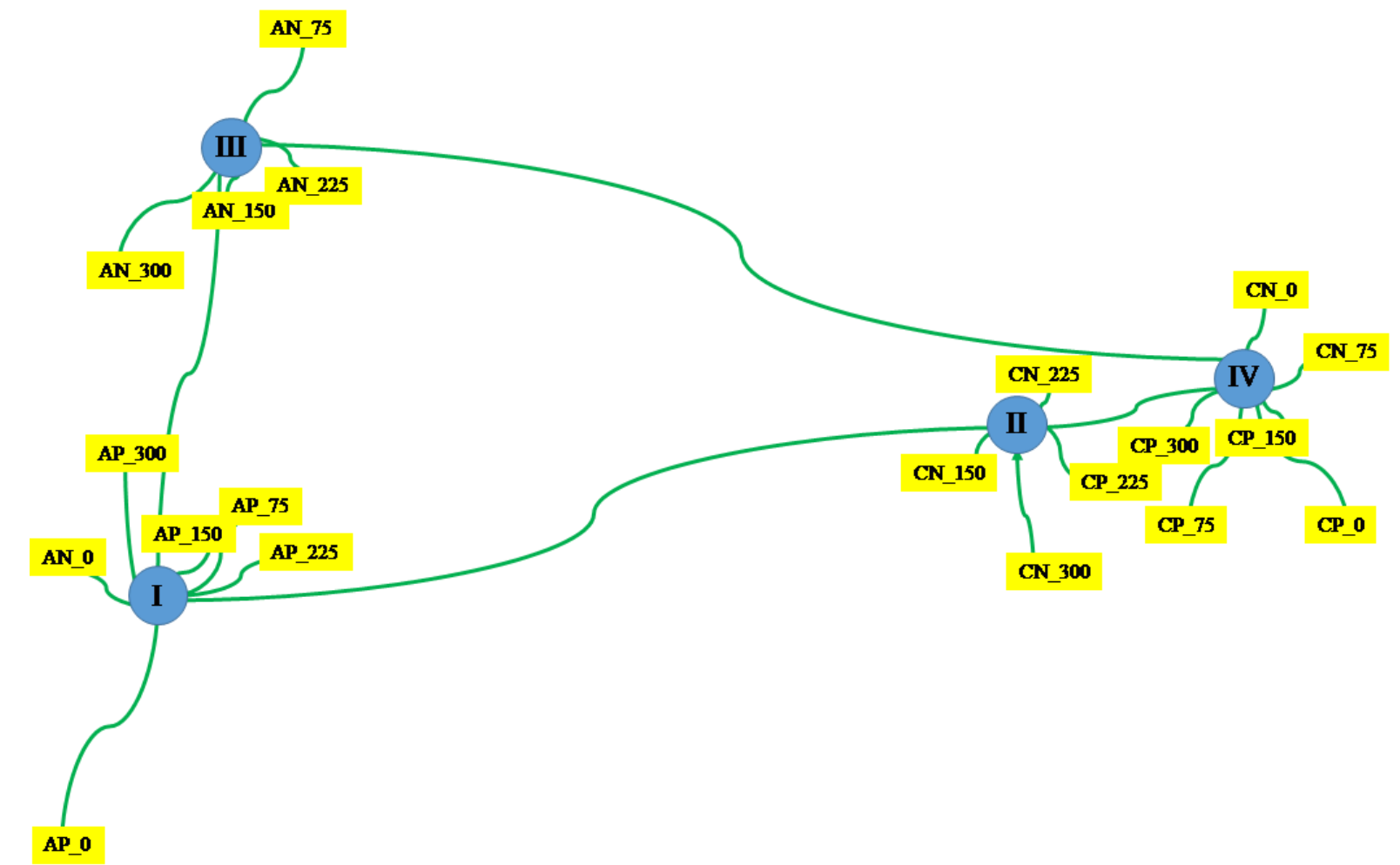

Figure 6. Artificial Neural Networks (RNAs) obtained by Kohonen Map defining centroids (blue) and neurons (green) and synaptic links (blue lines), for combinations of lettuce genotypes (Americana - A and Crespa - C), nitrogen sources (Polyblen - $\mathrm{P}$ and NitroMais - $\mathrm{N}$ ) in different nitrogen contents ( 0 , 75, 150, 225 and $300 \mathrm{~kg}$ of $\mathrm{N} \mathrm{ha}^{-1}$ ). UNIFIMES, Mineiros-GO, Brazil, 2020.

Centromere III was housed by NitroMais fertilized lettuce neurons, and this was the tendency for the other centromeres, in which neurons initially adjusted for the source of genetic variation; followed by the nitrogen source, noting that the nitrogen source content in the synaptic organization of the proposed neural network was of little influence (Figure 6). Azevedo et al. (2017) pointed to the high phenotypic and genotypic correlation estimated by RNA for the selection of superior genotypes. Abraham et al. (2019) proposed RNA model to make soybean crop predictions, concluding that the proposed model met expectations with minimal errors, showing multiple correlation between the variables.

The analysis of variance described the interaction between Crespa and Americana lettuce genotypes, with Polyblen and NitroMais sources of nitrogen fertilizers with their respective contents. The values of ALT plant height, DCL stem diameter, DCA head diameter, NFC commercial leaf number and fresh weight of PFC head of lettuce genotypes were divided into simple effects; and principal through their means and regression models; thus adjusting the best performances. Correlations were paired variable by variable in the analysis of simple correlations and measured on the trail. The treatments were further classified into similarity groups through the phylogenetic tree and their degree of affinity with the characteristics taken in the canonical variable analysis and through the neural network we can better organize the treatment pairing.

In conclusion, multivariate pairing in alfaciculture revealed the great correlation between the characters analyzed, and their variability in genotypes, controlled release nitrogen technologies and their respective 
concentrations. In the univariate pairing it was found that for high performance of alfacicultura in the genotype Americana cv. Lucy Brown recommends the application of controlled release nitrogen Polyblen at a concentration of 217.50 and NitroMais at $174.38 \mathrm{~kg} \mathrm{ha}^{-1}$ of $\mathrm{N}$, as well as the Polyblen source at a dose of $146.50 \mathrm{~kg} \mathrm{ha}^{-1}$ of N in the Crespa cv. Vanda.

\section{References}

Abraham ER et al. 2019. Estimation of Brazilian soybean production using artificial neural networks. Agrarian 44:261-271.

Almeida REM. 2016. Increased fertilizers: use of controlled release urea or inhibitors in agricultural systems. Embrapa Fishing and AquacultureDocuments (INFOTECA-E). 28p.

Araújo WF et al. 2011. Lettuce response to nitrogen fertilization. Agro@mbiente Magazine Online 5:12-17.

Auler AC et al. 2015. Lettuce seedlings development index in different substrates using multivariate analysis. Scientific 43:50-57.

Awaad MS et al. 2016. Effects of different nitrogen and potassium sources on lettuce (Lactuca sativa L.) yield in a sandy soil. Eurasian Journal of Soil Science 5:299-306.

Azevedo AM et al. 2017. Increased leaf selection efficiency in cabbage using artificial neural networks. Brazilian Horticulture 35:14-19.

Bhering LL. 2017. Rbio: A tool for biometric and statistical analysis using the R platform. Crop Breeding and Applied Biotechnology 17:187-190.

Costa RB et al. 2015. Univariate and Multivariate Analysis: importance for the genetic improvement of forest species with emphasis on Eucalyptus camaldulensis Dehnh. Multitemes 44:13-25.

Cruz CD et al. 2004. Biometric models applied to genetic improvement. 3.ed. Viçosa, MG: UFV, 480p.

Cruz CD. 2016. Genes Software - extended and integrated with the R, Matlab and Selegen. Acta Scientiarum 38:547-552.

Dutra SMF. 2018. Multivariate analysis for characterization and divergence of genotypes and correlation between characters in maize. UNESP Institutional Repository, 48.

Santos, HG et al. 2018. Sistema brasileiro de classificação de solos. Brasília, DF: Embrapa, 2018.

Embrapa. 2009. Manual of soil analysis methods. 2.ed. rev. current. - Rio de Janeiro. p.627: il. (EMBRAPA-CNPS. Documents, 1).

Ferreira LL et al. 2019. Components of maize crop as a function of doses of polymerized urea. Journal of Agricultural Science 11:185-192.

Köppen W and Geiger R. 1936. Handbook of Climatology. Gebrüder Borntraeger, Berlin.

Melo GG et al. 2018. Influence of different levels of nitrogen fertilization on the yield of lettuce cultivars. Health \& Science Online Magazine 7:276-285.

Nascimento MV et al. 2017. Manejo da adubação nitrogenada nas culturas de alface, repolho e salsa. Journal of neotropical agriculture 4:6571.

Oliveira LADA et al. 2017. Agro-economic efficiency of polycultures of arugula-carrot-lettuce fertilized with rooster tree at different population density proportions. Revista Brasileira de Engenharia Agrícola e Ambiental 21:791-797.

Pedrinho DR et al. 2015. Cultivation of lettuce fertilized with controlled release nitrogen fertilizer and urea. Bioscience Journal 31:997-1003.

Rezende $\mathrm{R}$ et al. 2017. Production and commercial quality of nitrogen and potassium fertigated lettuce in protected environment. Ceres Magazine 64:205-211.

Silva E et al. 2017. Lettuce performance under the application of chemical and organic fertilizers. Science ET Praxis $9: 21-24$.

Silva RCPD et al. 2018. Effect of Rooster Tree Green Manure on Carrot and Lettuce Intercropping System. Caatinga Magazine 3:551-559.

Silva WW et al. 2019. Evaluation of protected fertilizers on maize yield. Humanities and technology (FINOM) 1:7-16.

Yeshiwas Y, et al. 2018. Effect of Nitrogen Fertilizer and Farmyard Manure on Growth and Yield of Lettuce (Lactuca sativa L.) Agricultural Research 13:74-79. 